\title{
Pembaruan kalender masehi Delambre dan implikasinya terhadap jadwal waktu Salat
}

\author{
Muhammad Himmatur Riza \\ Fakultas Ekonomi dan Bisnis Universitas Dian Nuswantoro Semarang (UDINUS) \\ Jl. Imam Bonjol No.207, Pendrikan Kidul, Kec. Semarang Tengah, \\ Kota Semarang, Jawa Tengah \\ Email: muhammadhimmaturriza@gmail.com \\ Ahmad Izzuddin \\ Fakultas Syariah dan Hukum UIN Walisongo Semarang \\ Jl. Walisongo No.3-5, Tambakaji, Kec. Ngaliyan, Kota Semarang, Jawa Tengah \\ Ketua Umum Asosiasi Dosen Falak Indonesia (ADFI) \\ Email: izzuddin@walisongo.ac.id
}

\begin{abstract}
Abstrak
Kalender Masehi merupakan sistem penanggalan berbasis Matahari (Solar System), yakni menggunakan peredaran Bumi mengelilingi Matahari yang berjumlah 365,2425 hari dalam satu tahun. Penentuan awal waktu salat juga mengacu pada kalender Masehi tersebut. Seiring berkembangnya ilmu pengetahuan, muncul sebuah fakta bahwa nilai rata-rata kalender Gregorian memiliki selisih 0,0003 hari per tahun dengan nilai tahun tropis saat ini. Selisih itu akan terakumulasi menjadi 1 hari dalam 3600 tahun. Hal ini menjadi alasan untuk melakukan pembaruan kalender Masehi. Seorang astronom Prancis bernama Jean Baptiste Joseph Delambre mengusulkan gagasannya dalam memperbarui sistem aturan yang ada pada kalender Gregorian, yakni panjang satu tahun sipil rata-rata 365 hari 5 jam 48 menit 48 detik atau 365,2422 hari. Dalam 3600 tahun ada 872 kali interkalasi, artinya menhapus 1 hari dari interkalasi tahun Gregorian dan tahun 2800 dipilih sebagai tahun kabisat yang diubah menjadi tahun basitoh. Sehingga dalam jadwal waktu salat pada tahun 2800 terdapat selisih awal waktu salat pada tanggal 29 Februari dan tanggal 1 Maret.
\end{abstract}

Kata Kunci: Gagasan Delambre, pembaruan kalender masehi, jadwal waktu salat

\begin{abstract}
Gregorian calendar is the Solar System, which uses the Earth's circulation around the sun, which amounted to 365,2425 days in one year. The determination of beginning of prayer times also refer to Gregorian calendar either. In fact, as the science goes on, for now the mean of Gregorian calendar year has 0,0003 second residual error with the mean of tropical year. This value will accumulated become one day in 3600 years. A French astronomer named Jean Baptiste Joseph Delambre proposed his idea in updating the existing regulatory system on the Gregorian calendar, namely the length of one civil year an average of 365 days 5 hours 48 minutes 48 seconds or 365.2422 days. In 3600 years there were 872 intercalations, meaning that removing 1 day from the intercalation of the Gregorian year and 2800 was chosen as a leap year that was changed to the common year. So that the prayer time schedule in 2800 there is the difference between the initial prayer time on February 29 and March 1.
\end{abstract}

Keywords: Delambre proposal, gregorian calendar reform, prayer times schedule

\footnotetext{
Pendahuluan

$\mathcal{P}$ enanggalan Masehi merupakan penanggalan yang paling familiar dengan masyarakat Indonesia karena digunakan sebagai penanggalan umum untuk kehidupan sehari-hari. Penanggalan ini sebenarnya merupakan
} 
$164 \mid$ Muhammad Himmatur Riza \& Ahmad Izzuddin

penanggalan Gregorian, yaitu sistem penanggalan yang dibangun oleh Paus Gregorius XIII ${ }^{1}$ yang perhitungan tahunnya dimulai dari lahirnya Isa al-Masih. Oleh karena itu kalender ini juga disebut dengan kalender Masehi yang merujuk pada Isa al-Masih. Sebutan Masehi inilah yang lebih populer bagi masyarakat Indonesia dibandingkan istilah-istilah yang lain.

Dalam bahasa Inggris terdapat istilah Common Era yang disingkat CE untuk penanggalan ini, dan waktu sebelum tahun 1 dipakai istilah Before Common Era yang disingkat BCE. Waktu sebelum tahun 1 ini juga disebut dengan istilah Before Christ yang disingkat BC yang artinya sebelum kelahiran Kristus. Istilah inilah yang kemudian di Indonesia-kan menjadi istilah Sebelum Masehi atau disingkat SM. ${ }^{2}$

Namun setelah diadakan penelitian, istilah SM ini menjadi kurang tepat karena didapati bahwa Isa al-Masih tidak dilahirkan tepat tahun 1, tetapi 4 atau 5 tahun sebelumnya. Oleh karena sebutan yang lebih tepat adalah STU atau Sebelum Tarikh Umum yang merupakan pengindonesiaan dari istilah Before Common Era. Sementara untuk waktu sesudah tahun 1 disebut TU yaitu Tarikh Umum. ${ }^{3}$

Dibandingkan dengan penanggalan internasional lainnya yang berkembang di Indonesia, kalender Masehi tampak sudah mapan karena tidak ada perselisihan dalam hal penentuan awal bulannya. Namun untuk mencapai kemapanan seperti yang tampak saat ini bukanlah dicapai dengan mudah. Kalender ini pernah mengalami beberapa kali koreksi karena adanya kesalahan didalamnya. Selain itu juga pernah terjadi penolakan-penolakan terhadapnya oleh masyarakat dunia. Butuh proses dan waktu yang panjang untuk mencapai kemapanan seperti saat ini.

Kemapanan yang tampak pada kalender Masehi ini sebenarnya juga bukan kemapanan yang final. Kalender Masehi seperti saat ini tidak bisa digunakan untuk jangka waktu yang panjang karena akan menyebabkan ketidaksesuaian dengan alam. Hal ini disebabkan adanya perbedaan antara satu tahun tropis Matahari dengan satu tahun Gregorian. Yang mana satu tahun tropis Matahari rata-rata adalah 365,242199 hari dan satu tahun Gregorian memiliki lama 365,2425 hari. Maka antara tahun Gregorian dengan siklus tahun tropis memunculkan selisih sekitar 0,0003 hari atau 12 detik setiap tahunnya. Selisih tersebut akan mengakibatkan fenomena astronomis seperti Vernal Equinox akan selalu terjadi 12 detik lebih awal dari tahun sebelumnya. Jika diakumulasikan 12 detik tersebut maka dalam kurun waktu 3600 tahun akan menjadi 1 hari, dalam kurun waktu 7200 tahun akan menjadi 2 hari 12 detik tersebut maka dalam 10.000

1 Ugo Baugompagni lahir di Bologna dari keluarga terhormat pada tahun 1502, ia mampelajari hukum dan menjadi Hakim sekaligus dosen di Universitas Bologna. Ia kemudian diangkat menjadi pemimpin umat Katolik seluruh dunia pada tahun 1572. Lihat August Ziggelaar, “The Papal Bull of 1582 Promulgating A Reform of the Calendar," in Gregorian Reform of The Calendar (Vatikan: Pontifica Academia Scientarium, 1983), p. 201.

${ }^{2}$ Muh. Ma'rufin Sudibyo, Sang Nabi Pun Berputar (Solo: Tinta Medina, 2011), p. 2.

${ }^{3}$ Penggunaan STU dan TU ini pertama kali disarankan oleh mantan rektor UGM, Teuku Jacob, lihat, Ibid., p. 2. 
tahun akan menjadi 3 hari dan dalam 100.000 tahun selisih antara Vernal Equinox akan menjadi 30 hari atau satu bulan dari tahun sebelumnya. ${ }^{4}$ Oleh karena itu dimungkinakan adanya perubahan dan koreksi lagi untuk penanggalan ini.

Meskipun nilai ini masih sangat kecil, jika diabaikan dan tidak segera diperbarui akan mempengaruhi berbagai kepentingan manusia terhadap penggunaan kalender. Perbedaan (Selisih) Gregorian dan tahun tropis tersebut juga nantinya akan berdampak pada data-data astronomis seperti deklinasi matahari dan equation of time dalam penentuan awal waktu salat, awal bulan dan arah kiblat. Sungguh permasalahan ini harus ditanggapi dengan serius oleh warga dunia.

Seorang Astronom berkebangsaan Prancis bernama Jean Baptiste Joseph Delambre mengemukakan gagasannya mengenai pembaruan kalender Gregorian dalam bukunya yang berjudul Astronomie Théorique Et Pratique: Tome Troisième. ${ }^{5}$ Menurutnya, Kalender Gregorian sudah kehilangan fungsinya pada tahun-tahun setelah tahun $3600 \mathrm{M}$. Ia mengusulkan sebuah aturan baru dalam menentukan tahun-tahun kabisat pada kalender Gregorian. Pembaruan kalender Gregorian akan dapat mempengaruhi sistem penggunaan kalender untuk menentukan ibadah umat Islam. Mengingat untuk menentukan waktu-waktu ibadah tersebut membutuhkan kalender untuk dapat mengetahui posisi Matahari. Dihilangkannya satu hari pada kalender Gregorian menyebabkan perhitungan untuk menemukan data-data astronomis menggunakan kalender dalam jadwal waktu salat juga harus disesuaikan.

Nilai dari hasil pengguaan metode dan data yang tidak akurat dapat mengurangi keabsahan ibadah seorang Muslim. Sehingga timbul pernyataan mengenai implikasi yang muncul dari gagasan Joseph Delambre terhadap penentuan awal waktu salat. Oleh karena itu penulis mengkaji dan menganalisa gagasan Delambre sebagai usulan pembaruan kalender Masehi (Gregorian) dan implikasinya terhadap jadwal waktu salat.

\section{Definisi penanggalan}

Penanggalan dalam pemahaman modern masyarakat umum lebih dikenal dengan nama kalender. Dalam Kamus Besar Bahasa Indonesia kalender memiliki makna yang sama dengan penanggalan, almanak, takwim, dan tarikh. ${ }^{6}$ Dari segi bahasa sebagaimana dalam Encyclopedia Britannica, kalender atau calendar berasal dari bahasa latin yaitu calendarium, yang berarti daftar bunga atau buku rekening. Kata calendar juga merupakan derivasi dari kata kalendae yang merupakan hari pertama sebuah bulan dalam kalender Republik Romawi juga bermakna sebagai

\footnotetext{
${ }^{4}$ Moedji Raharto, "Tinjauan Reformasi Kalender Surya," in Prosiding Seminar Sehari Astronomi (Bandung: Jurusan Astronomi ITB-Himpunan Astronomi Indonesia, 1995), p. 243.

${ }^{5}$ Jean Baptiste Joseph Delambre, Astronomie Théorique et Pratique Tome Troisiéme, 3rd ed. (Paris: Mme Ve COURCIER, Imprimeur-Libraire pour les Mathématiques, 1814), p. 201.

${ }^{6}$ Suharso dan Ana Retnoningsih, Kamus Besar Bahasa Indonesia, 8th ed. (Semarang: CV. Widya Karya, 2009), p. 526
} 
$166 \mid$ Muhammad Himmatur Riza \& Ahmad Izzuddin

hari adanya pasar, pesta, dan acara-acara lainnya yang diproklamirkan. ${ }^{7}$ Definisi kalender disimpulkan dengan pernyataan kalender dengan sistem apapun untuk membagi waktu selama periode yang diperpanjang seperti hari, bulan atau tahun dan mengatur pembagian tersebut dalam urutan yang pasti. ${ }^{8}$

Definisi kalender menurut beberapa ahli Astronomi, seperti E. G. Richards dalam buku berjudul Mapping Time: the Calendar and Its History menyebutkan bahwa kalender adalah skema untuk mengelompokkan hari-hari menjadi unit yang lebih panjang, bulan, dan pengelompokkan bulan ke tahun, namun terkadang pengelompokkan bisa lebih kecil dari bulan seperti mingguan. ${ }^{9}$

Definisi lainnya sebagaimana dalam buku karya Peter Duffett-Smith, kalender didefinisikan sebagai sistem perhitungan hari dalam waktu satu tahun yang terbagi menjadi bulan, minggu, dan hari. Dalam bukunya ia menjelaskan definisi kalender Masehi dengan menguraikan konsep sistem kalender Julian yang diperkenalkan oleh Julius Caesar dan Gregorian yang diperkenalkan oleh Pope Gregory pada tahun $1582 \mathrm{M}$ dan diterima di Inggris pada tahun $1752 \mathrm{M} .{ }^{10}$

Kata kalender dijelaskan oleh para ahli Falak dengan menggunakan istilah dan pengertiannya masing-masing. Ahmad Izzuddin mendefinisikan kalender adalah suatu sistem waktu yang merefleksikan daya dan kekuatan suatu peradaban. ${ }^{11}$ Susiknan Azhari menggunakan istilah kalender dari makna sosiologisnya yaitu sebagai sistem pengorganisasian dari satuan-satuan waktu untuk tujuan penandaan rencana aktifitas secara terkontrol serta perhitungan waktu dalam jangka panjang sampai satu tahun. Kalender terkait erat dengan peradaban manusia karena memiliki peran penting dalam menentukan rancangan waktu berburu, bertani, berimigrasi, peribadatan, dan perayaan-perayaan hari penting. ${ }^{12}$ Ruswa Darsono dalam bukunya menyebut istilah kalender dengan sistem pengorganisasian satuan-satuan waktu yang dengannya permulaan, panjang dan pemecahan bagian tahun ditetapkan yang bertujuan menghitung waktu melewati jangka yang panjang. ${ }^{13}$

Abdul Karim dan Rifa Jamaluddin menggunakan istilah tārikh (penanggalan) untuk menyebutkan tiga macam kalender yang dibahas dalam bukunya, seperti menyebutkan tārikh Kamariah dengan istilah tārikh Arab. ${ }^{14}$ Kemudian Moedji Raharto menyebut prinsip dasar sistem penanggalan karena

\footnotetext{
${ }^{7}$ Elva Imeldatur Rohmah, “Kalender Cina Dalam Tinjauan Historis Dan Astronomis,” Jurnal Al-Marshad: Jurnal Astronomi Islam Dan Ilmu-Ilmu Berkaitan Juni (2018):, p. 33.

${ }^{8}$ Colin Alistair Ronan, Nicola Abdo Ziadeh, John D. Schmidt, E.J. Bickerman, Chao Lin, J.A.B.

van Buitenen, "Calendar Chronology," in Encyclopaedia Britannica, 2019, https://www.britannica.com/science/calendar.

9 E. G. Richards, Mapping Time: The Calendar and Its History (New York: Oxford University Press, 1999), p. 3.

${ }^{10}$ Peter Duffett-Smith and Jonathan Zwart Zwart, Practical Astronomy With Your Calculator or Spreadsheet, 4th ed. (New York: Cambridge University Press, 2011), p. 2.

${ }^{11}$ Ahmad Izzuddin, CV. Karya Abadi Jaya (Semarang: CV. Karya Abadi Jaya, 2015), p. 35.

12 Susiknan Azhari, Ensiklopedi Hisab Rukyat, 1st ed. (Yogyakarta: Pustaka Pelajar, 2005), p. 87.

13 Ruswa Darsono, Penanggalan Islam: Tinjauan Sistem, Fiqih Dan Hisab Penanggalan (Yogyakarta: Labda Press, 2010), p. 28.

${ }^{14}$ Abdul Karim and M. Rifa Jamaluddin Nasir, Mengenal Ilmu Falak: Teori Dan Implementasi (Yogyakarta: Qudsi Media, 2012), p. 23.
} 
kalender sebagai sistem penataan waktu, yaitu yang terletak pada penetapan awal penanggalan, aturan dari sistem penanggalan, definisi hari, definisi siklus yang lebih besar 7 hari, 1 bulan, 1 tahun dan seterusnya, garis batas pergantian tanggal atau hari, dan konsistensi sistem penanggalan berbagai catatan yang diperlukan agar tidak terjadi kekacauan dikemudian hari. Sedangkan makna terminologi kalender menurut Muh. Rasywan Syarif yakni kalender berbentuk tabel, data, dan daftar hari yang memberikan informasi serta penggorganisasian satuan-satuan waktu yang berulang-ulang pada siklusnya secara teratur, tertib dan terukur kepastian informasinya. ${ }^{15}$

Selain itu, terdapat beberapa literatur yang menggunakan istilah almanak dalam mendefinisikan kalender, salah satunya Slamet hambali. Menurutnya almanak merupakan sebuah sistem perhitungan yang bertujuan untuk pengorganisasian waktu dalam periode tertentu dengan bulan sebagai unit yang merupakan bagian dari almanak, hari sebagai unit almanak terkecil, kemudian sistem waktu yaitu jam, menit, dan detik. ${ }^{16}$ Badan Meteorologi Klimatologi dan Geofisika (BMKG) di Indonesia juga menggunakan istilah almanak dalam buku informasi tahunannya untuk memberikan informasi tanda waktu yang antara lain memuat informasi hari raya nasional dan hari-hari besar agama, penanggalan atau kalender Masehi, Islam, Jawa, China, dan Hindu, informasi fase-fase Bulan, waktu terbit terbenam Matahari, informasi gerhana Matahari dan Bulan. ${ }^{17}$

Beberapa definisi di atas memberikan informasi mengenai kalender atau penanggalan sebagai sebuah sistem untuk mengatur kronologi waktu secara baik dengan mengelompokkan satuan-satuan waktu dalam hari, minggu, bulan, dan tahun.

\section{Sejarah dan cikal bakal kalender masehi}

Kalender Romawi merupakan cikal bakal dari kalender Masehi. Kalender ini diproklamirkan penggunaannya oleh Numa Pompilus pada tahun berdirinya kerajaan Romawi pada tahun 753 STU. ${ }^{18}$ Kalender Romawi Numa Pompulis sebenarnya merupakan pembaharuan dari kalender Romawi kuno yang dipopulerkan oleh penguasa sebelumnya yang terkenal dengan kelender yang hanya memiliki 10 bulan sebagaimana tradisi desimal yang ada pada mereka. Kalender 10 bulan tersebut menggunakan sistem penanggalan Bulan yang satu bulannya terdiri dari 30 hari atau 31 hari sehingga dalam satu tahun terdapat 305 hari. Kalender ini beredar di wilayah Romawi terutama di kota Antium. ${ }^{19}$

Numa Pompulis kemudian menambahkan 2 bulan sehingga jumlah bulan menjadi 12 dan acuan kalendernya dirubah menjadi kalender lunisolar atau kalender yang menggunakan acuan Matahari dan Bulan sebagaimana kalender

${ }^{15}$ Muh. Rasywan Syarif, Perkembangan Perumusan Kalendar Islam Internasional (Studi Atas Pemikiran Mohammad Ilyas) (Yogyakarta: Disertasi Pascasarjana UIN Sunan Kalijaga, 2017), p. 33.

16 Slamet Hambali, Almanak Sepanjang Masa: Sejarah Sistem Penanggalan Masehi, Hijriyah Dan Jawa (Semarang: Program Pascassarjana IAIN Walisongo, 2011), p. 3.

${ }^{17}$ Badan Meteorologi Klimatologi dan Geofisika, Almanak 2018 (Jakarta: BMKG, 2017), p. i.

${ }^{18}$ Muhyiddin Khazin, Ilmu Falak Dalam Teori Dan Praktik(Yogyakarta: Buana Pustaka, 2004), p. 103.

${ }^{19}$ Muh. Hadi Bashori, Penanggalan Islam (Jakarta: PT Elex Media Computindo, 2013), p. 262-263. 
$168 \mid$ Muhammad Himmatur Riza \& Ahmad Izzuddin

Yahudi. Dalam kalender ini terdapat 7 bulan yang terdiri dari 29 hari, 4 bulan yang terdiri dari 31 hari dan 1 bulan yang terdiri dari 28 hari, sehingga satu tahun memiliki 355 hari. Dalam sistem penanggalan Romawi Lunisolar ini mempunyai bulan sisipan yang dinamakan bulan Marcedonius sebagai bulan ke 13. ${ }^{20}$ Interkalasi atau penambahan bulan ke 13 dalam kalender ini dilakukan dengan sewenang-wenang oleh otoritas kepausan. ${ }^{21}$

Nama-nama bulan dalam kalender ini adalah: Martius, Aprilis, Maius, Junius, Quintilis, Sextilis, September, October, November, December, Januarius, Februarius. Nama-nama bulan tersebut diambil dari dewa-dewa bangsa Romawi seperti Marius yang diambil dari Dewa Mars, Maius dari Dewa Maia dan Junius dari Dewa Juno. Sedangkan nama bulan yang lainnya merupakan nama yang diberikan berdasarkan angka urutan dari susunan bulannya. Quintilis yang berarti bulan ke lima, Sextilis bulan ke enam, September bulan ketujuh, October bulan delapan dan seterusnya. Adapun nama bulan Aprilis diambil dari kata Aprieri yang berarti sebutan untuk cuaca yang nyaman dalam musim semi. ${ }^{22}$

Bulan pertama dalam penanggalan ini adalah Martius karena vernal equinox terjadi pada bulan ini. Pemindahan bulan pertama menjadi bulan Januarius ini dilakukan pada tahun 153 STU oleh Pontivex Maximus ${ }^{23}$ atau ketua dari lembaga perwakilan. ${ }^{24}$ Pendapat lain mengatakan bahwa pemindahan bulan Januarius menjadi bulan pertama dilakukan saat Dewan Gereja bersidang untuk yang pertama kalinya yang dilaksanakan pada bulan Januari yang kemudian sistem ini dinamakan sistem Yustinus. ${ }^{25}$ Sementara pendapat yang lain lagi menyatakan bahwa pemindahan Januarius sebagai awal tahun dilakukan oleh Julius Caesar saat mereformasi kalender ini. ${ }^{26}$

\section{Reformasi Julius Caesar}

Pada tahun 63 STU Julius Caesar terpilih menjadi Pontivex Maximus. Salah satu kebijakannya yang sangat terkenal adalah mereformasi sistem kalender Romawi yang dilakukannya pada tahun $46 \mathrm{SM}^{27}$. Hasil dari reformasi sistem kalender Romawi ini kemudian dikenal dengan nama kalender Julian. Adapun beberapa kebijakan yang diambilnya dalam merubah sistem kalender ini adalah:

\footnotetext{
${ }^{20}$ Ahmad Ghozali, Irsyāed Al-Murīd Ilaā Márifah 'Ilm Al-Falāk 'Alā Raṣd Al-Jadìd (Sampang: LAFAL, 1436 H), p. 54.

${ }^{21}$ H. M Nautical Almanac Office, Explanatory Supplement to The Astronomical Ephemeris and The American Ephemeris and Nautical Almanac (London: Her Majesty's Stationery Office, 1961), p. 410.

22 Bashori, Penanggalan Islam, p. 263.

${ }^{23}$ Pontifex Maximus adalah imam besar dari lembaga Majelis Pontif pada zaman Romawi Kuno, Pontifex Maximus jabatan terpenting dalam agama Romawi Kuno yang mula-mula hanya boleh dijabat oleh seorang patricius (bangsawan), sebelum akhirnya dijabat oleh seorang plebs (rakyat jelata) untuk pertama kalinya pada 254 SM. Lihat http://id.dbpedia.org/page/Pontifex_Maximus.

${ }^{24}$ Ghozali, Irsyād Al-Murìd Ilaā Ma'rifah 'Ilm Al-Falāk 'Alā Raṣd Al-Jadīd, p. 54.

${ }^{25}$ Bashori, Penanggalan Islam, p. 263.

${ }^{26}$ Ahmad Musonnif, Ilmu Falak (Yogyakarta: Teras, 2011), p. 100.

${ }^{27}$ Mengenai tahun dimana Julius Caesar mereformasi kalender Romawi ini terdapat dua pendapat, pendapat pertama adalah pendapat yang paling banyak disebutkan adalah tahun $46 \mathrm{SM}$, sedangkan pendapat kedua menyatakan 47 SM.
} 
1. Mengubah sistem kalender Romawi menjadi kalender yang menggunakan sistem Matahari. Sistem ini dipelajarinya dari kalender Matahari Mesir. Orangorang Mesir sudah lama menggunakan Matahari sebagai acuan sistem penanggalan mereka. Dari catatan sejarah, sistem penanggalan Matahari tersebut telah dikenal bangsa Mesir sejak 4241 STU. Penggunaan kalender yang bersesuaian dengan siklus tropis ini bertujuan untuk mengetahui kapan meluapnya sungai Nil, musim tanam dan musim panen. ${ }^{28}$

2. Menyisipkan 23 hari dalam bulan Februari dan 67 hari diantara bulan November dan Desember sehingga pada tahun 46 STU mempunyai jumlah hari sebanyak 445 hari. ${ }^{29}$

3. Menetapkan 1 Januarius sebagai awal tahun dan menetapkan umur tahun ratarata adalah 365,25 hari atau 365 hari 6 jam.

4. Menetapkan siklus 4 tahun, yang salah satu diantara 4 tahun tersebut terdapat tahun kabisat (berumur 366 hari) dengan penambahan satu hari pada bulan Februarius. Penambahan satu hari ini adalah akibat dari adanya lebihan 6 jam dalam satu tahun menurut perhitungan mereka. 6 jam tersebut jika dikumpulkan selama empat tahun maka akan menjadi satu hari. ${ }^{30}$

5. Menetapkan bulan Januarius, Martius, Maius, Quintilis, September dan November berumur 31 hari, sedangkan bulan Aprilius, Junius, Sextilis, October dan Desember berumur 30 hari. ${ }^{31}$

Aturan-aturan baru tersebut mulai diberlakukan pada tahun 45 STU. Dalam menetapkan aturan-aturan tersebut, Julius Caesar dibantu oleh ahli astronomi dan perhitungan dari Alexandria yang bernama Sosigenes. ${ }^{32}$ Atas jasanya itu, Pontivex Maximus yang saat itu dijabat oleh Mark Anthony mengubah nama bulan yang ke tujuh yakni Quintilis menjadi Julius. ${ }^{33}$

Pada masa selanjutnya, tepatnya pada tahun 7 STU, penerus dari Julius Caesar yang bernama Augustus melakukan koreksi terhadap kalender ini. Ia menghapus tahun-tahun kabisat dari tahun 8 STU sampai tahun 8 TU. Lalu sejak tahun 8 TU ia mengembalikan kabisat seperti asalnya. Selain itu ia juga mengubah jumlah hari pada bulan ke-delapan menjadi 31 hari. Sehingga bulan October dan Desember juga ikut berubah menjadi 31 hari, sedangkan November dan September menjadi 30 hari. Atas idenya tersebut nama bulan ke delapan yang asalnya Sextilis diubah menjadi Augustus dan tetap bertahan sampai sekarang. ${ }^{34}$

Penetapan permulaan dari perhitungan tahun ini baru ditetapkan pada tahun 525 TU atau 560 tahun setelah ditetapkannya aturan-aturan Julius. Penetapan ini dilakukan oleh pendeta Dyonsius Exiqus yang menetapkan lahirnya Nabi Isa sebagai permulaan perhitungan tahun. Dengan demikian maka

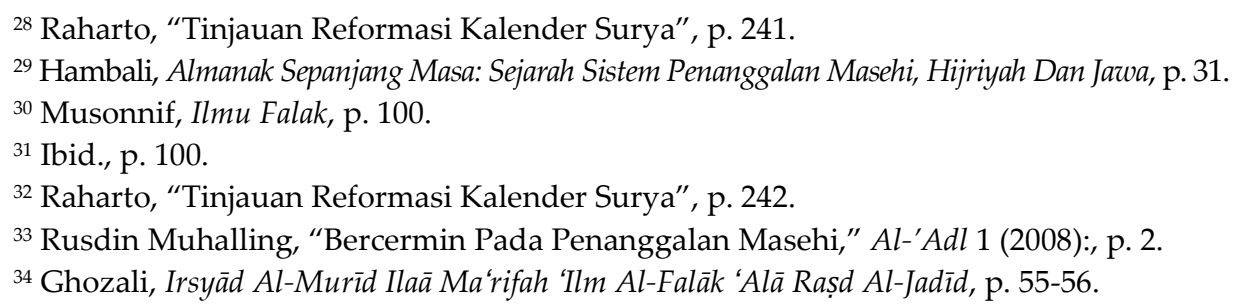


$170 \mid$ Muhammad Himmatur Riza \& Ahmad Izzuddin

dilakukan perhitungan mundur dan didapati pada saat itu bahwa tahun yang berjalan adalah tahun $525 .{ }^{35}$

\section{Koreksi Gregorius XII terhadap kalender Julian}

Pada tahun 1582, Ugo Bougompagni atau yang lebih dikenal dengan Paus Gregorius XIII ${ }^{36}$ menyoroti perhitungan dalam kalender Julian. Dengan dibantu ahli matematika Christopher Clavius serta ahli astronomi Lilio Ghiraldi atau yang lebih dikenal dengan Aloysius Lilius, ${ }^{37}$ ia membuat keputusan untuk memotong hari 10 hari sehingga pada saat itu yang bertepatan dengan hari Kamis tanggal 4 Oktober 1582 keesokan harinya yang asalnya tanggal 5 Oktober menjadi tanggal 15 Oktober. Sehingga bulan Oktober tahun 1582 hanya memiliki 21 hari. Pengurangan 10 hari tersebut bertujuan agar pada tanggal 21 Maret posisi Matahari berada pada Vernal Equinox, sementara pada tahun 1582 tersebut, Vernal Equinox terjadi pada tanggal 11 Maret, sehingga telah bergeser 10 hari. ${ }^{38}$ Penetapan tanggal 21 Maret sebagai Vernal Equinox ini bersesuaian dengan keputusan Konsili Nicea I pada tahun 325. Pada waktu itu para uskup gereja kristen di seluruh wilayah kekaisaran Romawi berkumpul di Nicea untuk membahas perbedaan-perbedaan yang terjadi diantara mereka. Salah satu yang menjadi pembahasan adalah waktu perayaan hari paskah yaitu hari Minggu pertama pada Vernal Equinox yang terjadi pada tanggal 21 Maret.

Selanjutnya, Gregorius juga menetapkan aturan tentang tahun kabisat, yakni tahun yang habis dibagi 400 untuk tahun ratusan dan tahun yang habis dibagi 4 untuk tahun yang satuan. Aturan baru ini mengubah tahun-tahun ratusan yang semestinya menurut aturan Julian adalah tahun kabisat menjadi tahun basitah. Seperti tahun 1700 yang menurut aturan Julian termasuk tahun kabisat karena habis dibagi 4, sementara menurut Gregorian tahun tersebut bukanlah tahun kabisat karena 1700 tidak habis dibagi $400 . .^{39}$

Dengan mengurangi 3 tahun kabisat per 400 tahun ini maka satu tahun tropis menurut Gregorian adalah 365,2425 hari. Angka tersebut berbeda dengan aturan Julius yang menetapkan satu tahun tropis adalah 365,25 hari. Dalam menentukan panjang tahun tropis tersebut, tim reformis Gregorian menggunakan tabel yang disusun oleh dua ilmuan Yahudi yaitu Yehudah ben Mosheh dan Issac ben Sid, bekerjasama dengan penguasa Spanyol saat itu yaitu Raja Alfonso sehingga tabel tersebut dikenal dengan tabel Alfonso. Tabel tersebut diyakini merupakan karya orisinil dari ilmuan eropa, namun keaslian tabel tersebut kemudian diragukan. Penelitian Juluis Samso dari University of Barcelona yang

${ }^{35}$ Ibid., p. 55.

${ }^{36}$ Ugo Baugompagni lahir di Bologna dari keluarga terhormat pada tahun 1502, ia mampelajari hukum dan menjadi Hakim sekaligus dosen di Universitas Bologna. Ia kemudian diangkat menjadi pemimpin umat Katolik seluruh dunia pada tahun 1572. Lihat Ziggelaar, "The Papal Bull of 1582 Promulgating A Reform of the Calendar", p. 201.

${ }^{37}$ Pendapat lain mengatakan bahwa tim Gregorius XIII ini terdiri dari Ignazio Danti, Clishtop Claviusa dan Ignatius Patriach. Lihat Hambali, Almanak Sepanjang Masa: Sejarah Sistem Penanggalan Masehi, Hijriyah Dan Jawa, p. 37.

${ }^{38}$ Raharto, “Tinjauan Reformasi Kalender Surya”, p. 242.

${ }^{39}$ Hambali, Almanak Sepanjang Masa: Sejarah Sistem Penanggalan Masehi, Hijriyah Dan Jawa, p. 39. 
meneliti tentang asal usul dari tabel Alfonso ini menyatakan bahwa sebagian angka-angka dari tabel tersebut mempunyai kesamaan dengan tabel dari ilmuan muslim Spanyol, yaitu tabel karya al-Zarqali atau tabel al-Battani yang diterjemahkan kedalam bahasa Spanyol. ${ }^{40}$

Aturan-aturan tersebut dikeluarkan oleh Gregorius bersama timnya pada tanggal 24 Februari 1582 dalam buku yang berjudul Bulla Inter Gravitassimas. ${ }^{41}$ Dan kalender hasil koreksi dari Gregorius XIII ini kemudian dikenal dengan Kalender Gregorius. Kalender inilah yang digunakan secara luas oleh masyarakat dunia hingga saat ini, termasuk di Indonenesia yang dikenal dengan kalender Masehi. Namun kalender Gregorian ini sebenarnya tidak langsung diterima oleh masyarakat dunia. Proses penerimaan kalender Gregorian berlangsung kurang lebih hingga 3 abad. Hanya di negeri-negeri Italia, Prancis, Portugis dan Spanyollah yang langsung menggunakan kalender ini sejak tahun 1582. ${ }^{42}$ Keengganan menggunakan kalender Gregorian ini disebabkan karena masyarakat masih mengikuti keyakinan dan kepercayaan dari dewan gereja. Karena itulah pada tahun 1698, Erhad Weigel mengirim surat kepada raja-raja Eropa yang beragama protestan untuk menerima penanggalan Gregorian. Weigel mengatakan bahwa pemakaian penanggalan ini bukanlah berarti tidak mematuhi Paus, ini merupakan masalah ketepatan benda langit, bukan masalah agama. ${ }^{43}$

Negara-negara Protestan tersebut baru menerima penanggalan Gregorius pada awal abad ke 18. Inggris mulai menggunakan penanggalan ini pada tahun 1752. Kebijakan Inggris menerima kalender Gregorian ini diikuti negara-negara jajahannya termasuk juga Amerika. Sementara negara-negara Eropa timur yang menganut kristen ortodoks mulai menerima kalender ini setelah beakhirnya perang dunia I. Rusia mulai menggunakannya pada tahun 1918 dan Yunani baru menggunakannya pada tahun 1923. Meskipun telah menerima kalender Gregorian, namun khusus untuk perayaan hari Natal gereja-gereja ortodoks masih menggunakan kalender Julian. Gereja Ortodoks merayakan hari Natal pada tanggal 7 Januari, karena tanggal 7 Januari ini menurut hitungan kalender Julian adalah 25 Desember. ${ }^{44}$

Sementara di Indonedia, kalender Gregorius ini baru dipaai secara resmi pada tahun 1910 dengan adanya undang-undang Wet op het Nederlandsch Onderdaanschap. Sebelumnya masyarakat Indonesia menggunakan kalender Hijriah yang hingga awal abad ke-20, raja-raja di kerajaan Nusantara masih menggunakannya sebagai penanda waktu dalam kehidupan sehari-hari. ${ }^{45}$

\section{Gagasan Delambre tentang pembaruan kalender masehi}

\footnotetext{
${ }^{40}$ Raharto, "Tinjauan Reformasi Kalender Surya”, p. 243.

${ }^{41}$ Hambali, Almanak Sepanjang Masa: Sejarah Sistem Penanggalan Masehi, Hijriyah Dan Jawa, p. 37.

${ }^{42}$ Raharto, "Tinjauan Reformasi Kalender Surya", p. 243.

${ }^{43}$ Hambali, Almanak Sepanjang Masa: Sejarah Sistem Penanggalan Masehi, Hijriyah Dan Jawa, p. 42.

${ }^{4}$ Ibid., p. 42-43.

${ }^{45}$ Ibid., p. 43-44.
} 
Jean Baptiste Joseph Delambre adalah seorang astronom Prancis yang punya banyak andil dalam perkembangan Ilmu Astronomi dan Matematika. ${ }^{46}$ Tidak sedikit karya yang ia tulis dijadikan bahan rujukan oleh banyak astronom hingga saat ini. Salah satu idenya dibahas pada tulisan ini yaitu tentang usulannya dalam memperbarui kalender Masehi. Sebuah kalender yang paling akurat adalah kalender yang nilainya paling dekat dengan tahun tropis dalam jangka waktu yang sangat lama. Namun, menurut beberapa referensi yang penulis baca sampai saat ini, belum ada sebuah konsep kalender yang dapat memenuhi tantangan itu. Beberapa kalender yang diusulkan sebagai pemberu kalender Masehi dinilai tidak sesuai sehingga tidak dapat diterapkan. Ada banyak faktor yang jadi penyebab sulitnya penyesuaian kalender terhadap tahun tropis karena kalender melibatkan banyak aspek, seperti budaya, sosial, dan ilmu pengetahuan alam dan lain-lain. Sehingga untuk menemukan sebuah kalender yang akomodatif terhadap nilainilai tersebut sangat sulit diwujudkan.

Delambre mengklaim telah menemukan aturan penentuan tahun kabisat yang lebih dekat dengan tahun tropis dibandingkan dengan aturan Gregorian (Masehi). Delambre berpendapat bahwa aturan interkalasi kalender Gregorian (Masehi) masih memiliki perbedaan satu hari dalam 3600 tahun. Perbedaan tersebut adalah keterlambatan kalender Gregorian (Masehi) dalam menyesuaikan waktu dengan peristiwa astronomis yang terjadi secara alamiah. Perbedaan itu tentu saja bisa mempengaruhi pola kehidupan manusia yang aktivitas kesehariannya menggunakan kalender Gregorian (Masehi). Terlebih lagi apabila perbedaan ini diabaikan dalam waktu lama maka, betapa banyak sistem yang akan kacau oleh perbedaan ini. Usulan Delambre tentang pembaruan Masehi (Gregorian) adalah tindakan preventif agar dapat menghindari timbulnya kekacauan akibat perbedaan waktu antara kalender Gregorian (Masehi) dengan tahun tropis.

Kata tropis berasal dari bahasa Yunani, yakni Tropic yang memiliki arti kembali atau balik atau mencapai batas. Pengamatan tahun tropis kemungkinan telah berlangsung sejak 9 abad SM oleh ilmuan Yunani Hesoid dan Homer. Pengamatan Matahari dari satu tropik (posisi tertentu di bola langit) kembali ke tropik yang sama. Tradisi itu melahirkan definisi satu tahun tropis adalah selang waktu Matahari melewati Vernal Equinox dua kali berturut-turut. ${ }^{47}$

Pengamatan masa silam tidak membedakan antara satu tahun tropis dengan satu tahun sideris yang menggunakan bintang sebagai acuannya. Hasil penentuan satu tahun tropis Hipparchus yang dicatat dalam buku Almagest oleh Ptolemy. Pada saat itu diketahui bahwa satu tahun tropis adalah 365 hari 5 jam 55

\footnotetext{
${ }^{46}$ Jean Baptiste Joseph Delambre lahir di Kota Amiens, Prancis pada tanggal 19 September 1749 M / 6 Syawwal 1162 H dan meninggal di Kota Paris, Prancis pada tanggal 19 Agustus 1822 M / 1 Dzul Hijjah 1237 H. pada tahun 1771, Delambre kuliah di salah satu perguruan tinggi Pancis. Delambre memiliki peranan penting dalam perkembangan ilmu mekanika benda langit dan geodesi, menulis buku-buku referensi di bidang matematika astronomi, dan menerbitkan 6 Buku seri sejarah astronomi kuno hingga astronomi abad 17. Lihat Antonio E Ten, “Biography of Jean Baptiste Joseph Delambre," in Biographical Encyclopedia of Astronomers, ed. Dkk Thomas Hockey, Editor: Virginia Trimble, Thomas William (New York: Springer References, 2014), p. 54.

${ }^{47}$ Raharto, “Tinjauan Reformasi Kalender Surya”, p. 245.
} 
menit 12 detik (365.25 - 1/300 hari) atau 365.2467 hari. Beberapa textbook astronomi mendefinisikan satu tahun tropis Matahari dari Vernal Equinox kembali ke Vernal Equinox lagi. Menurut teori VSOP87, satu tahun tropis Matahari didefinisikan sebagai selang waktu yang dibutuhkan bujur ekliptika Matahari bertambah sebesar 360 derajat, satu tahun tropis Matahari saat itu adalah 365 hari 5 jam 48 menit 56 detik atau 365.2423 hari, artinya lebih cepat 0.0043 hari dari penentuan Hipparchus. ${ }^{48}$

Pemahaman dinamikan presisi dan posisi matahari berkembang secara akurat. Saat ini diketahui bahwa selang waktu Matahari dari Vernal Equinox ke Vernal Equinox berikutnya tidak konstan. Misalnya selang waktu dari Vernal Equinox tahun 1985 ke Vernal Equinox 1986 adalah 365 hari 5 jam 48 menit 58 detik. Sedang dari Vernal Equinox 1989 ke Vernal Equinox 1990 adalah 365 hari 5 jam 51 menit 6 detik. ${ }^{49}$ Gerak nutasi sumbu Bumi oleh bulan dan planet merupakan penyebab ketidak konstanan itu. Titik aries yang bergerak dan berubah-ubah itu sukar dijadikan acuan penentuan tahun tropis. Sebagai gantinya definisi tahun tropis yang digunakan saat ini adalah selang waktu yang dibutuhkan bujur ratarata matahari bertambah sebesar 360 derajat. Bujur tropis rata-rata itu ditentukan dari Vernal Equinox yang terpengaruh presisi. Dengan definisi tersebut satu tahun tropis mempunyai selang waktu yang sama dan memungkinkan untuk mengetahui konstan tidaknya revolusi Bumi..$^{50}$

Analisa jangka panjang yang dilakukan oleh Jean Meeus dan Denis Savoie mendapati bahwa satu tahun tropis itu mengalami perlambatan sebesar 0.5 detik per abad. ${ }^{51}$ Dengan kata lain periode revolusi Bumi memendek 0.00012 hari selama 2000 tahun. Untuk saat ini satu tahun tropis rata-rata dekat dengan angka 365.242199 hari. Dan pada suatu saat di masa depan satu tahun tropis bisa mencapai hanya 365 hari atau bahkan 360 hari.

Tidak seperti para astronom pendahulunya, yang menghitung panjang tahun tropis dari selang waktu matahari melewati Vernal Ekuinox dua kali berurutan. Menurut Delambre metode menghitung panjang satu tahun tropis adalah dengan menghitung perjalanan matahari pada bujur nya selama 365.25 hari. Alasannya Delambre telah mempertimbangkan penemuan Hipparchus tentang gerak presesi ekuinoks. Selain itu Delambre juga telah mengkaji metode perhitungan tahun tropis yang dilakukan oleh Copernicus, dari kajian itu Delambre mendapatkan pengetahuan bahwa perjalanan Matahari tropis nilainya tidak konstan. Sehingga Delambre mendapatkan bahwa panjang untuk satu tahun tropis sebesar 365 hari 5 jam 48 menit 51.6 detik. ${ }^{52}$

\begin{tabular}{|c|c|}
\hline Tahun & $\begin{array}{c}\text { Perubahan per } \\
\text { Abad }\end{array}$ \\
\hline
\end{tabular}

\footnotetext{
48 Jean Meeus dan Denis Savoie, “The History of Tropical Year,” Journal of Britannia Astronomic Association 102 (1992), p. 40.

${ }^{49}$ Ibid., p. 41.

${ }^{50}$ Raharto, "Tinjauan Reformasi Kalender Surya", p. 246.

${ }^{51}$ Savoie, "The History of Tropical Year", p. 42.

52 Ibid., p. 41.
} 
${ }_{174} \mid$ Muhammad Himmatur Riza \& Ahmad Izzuddin

\begin{tabular}{|c|l|}
\hline-1000 & -0.469 detik \\
\hline 0 & -0.503 detik \\
\hline 1000 & -0.524 detik \\
\hline 2000 & -0.532 detik \\
\hline 3000 & -0.526 detik \\
\hline 4000 & -0.505 detik \\
\hline
\end{tabular}

Tabel 1: Variasi perubahan rata-rata panjang tahun tropis per abad dalam rentang 5000 tahun $^{53}$

Penjelasan dari tabel di atas, dapat difahami bahwa panjang tahun tropis semakin lama semakin pendek. Perubahan panjang tahun tropis per abad berkurang dengan nilai yang relatif singkat namun tetap berbeda. Sehingga dapat disimpulkan bahwa panjang tahun tropis selalu berubah, panjang tahun tropis semakin tahun semakin berkurang menjadi lebih cepat, dan berkurangnya panjang tahun tropis sepanjang masa tidak koonstan atau berubah-ubah.

Definisi tahun tropis Delambre dapat ditelusuri pada buku karangannya yang berjudul: Abrégé d'astronomie, ou leçons élémentaire d'astronomie théorique et pratique, yaitu: ${ }^{4}$

"L'année déterminée par les équinoxes s'appelletropique, parce $q u$ 'anciennement on l'avait conclue du retourdu soleil à un même tropique. intervalle de temps comprisentre deux passages successifs $d u$ centre du soleil à l'équinoxede printemps; cette année differe de l'année sidérale à causedu déplacement de l'équinoxe de printemps, dî à la precession des équinoxes et à la nutation; elle est de 365 jours 5 heures 48 minutes 51.6 secondes, et ainsi plus courte de 24 minutes 8 secondes que l'année sidérale."

Artinya:

Tahun yang ditentukan oleh equinox disebut tropik, karena sebelumnya disimpulkan dari kembalinya matahari ke titik equinox yang sama. selang waktu antara dua laluan yang berurutan dari pusat matahari ketitik balik musim semi; tahun ini berbeda dari tahun sidereal disebabkan oleh gerak presesi equinox dan nutasi yang menyebabkan perpindahan Vernal Equinox, sehingga, panjang tahun tropis 365 hari 5 jam 48 menit 51.6 detik,dan dengan demikian 24 menit 8 detik lebih pendek dari tahun sidereal.

Beberapa astronom berbeda-beda mendefinisikan tahun tropis dari tahun ke tahun. Hal tersebut dikarenakan dua hal: Pertama, Equinox secara perlahan bergeser sepanjang lingkaran ekliptika. Kedua, ketika Matahari telah melewati Vernal Equinox dua kali berurutan, perjalanan Matahari belum memenuhi satu putaran karena ada pergerakan osilasi ${ }^{55}$ akibat gerak nutasi Bumi.

\footnotetext{
53 Ibid., p. 42.

${ }^{54}$ Jean Baptiste Joseph Delambre, Abrégé d'astronomie, Ou Leçons Élémentaired'astronomie Théorique et Pratique (Paris: Mme Ve COURCIER, Imprimeur-Libraire pour les Mathématiques, 1833), p. 297.

${ }^{55}$ Osilasi adalah variasi periodik terhadap waktu dari suatu hasil pengukuran.
} 
Fokus pada tulisan ini bahwa kalender Masehi merupakan penanggalan yang mengacu pada kalender Gregorian yang dirumuskan oleh dewan astronomi Gereja Katolik Roma pada tahun 1582. Kalender Gregorian merupakan pembaharuan dari kalender Julian. Yang mana kalender Julian mempunyai sistem interkalasi hari yang paling sederhana dari semua kalender yang menggunakan interkalasi. Satutahun rata-rata kalender Julian adalah 365.25 hari. Artinya kalender Julian mempunyai tempo lebih lama 11 menit dan 14 detik dalam setahun dibandingkan dengan tahun tropis $(365.25-365.242199=0.007801)$. Kelebihan tersebut dalam 150 tahun dapat terakumulasi hingga 28 jam lebih yang menyebabkan peristiwa astronomis terjadi lebih awal dari tanggal yang telah ditentukan. Pergerakan ini sangat lambat sehingga seseorang tanpa penelitian astronomis tidak akan dapat menyadari perubahan itu.

Delambre menganggap kalender Gregorian harus direformasi kembali. Karena akan sangat berguna apabila kalender dapat ditentukan dan diperbaiki sehingga benar-benar akurat dan agar dapat menjadi panutan waktu. pernyataan Delambre tentang pembaruan kalender Gregorian, sebagai berikut: ${ }^{6}$

"Je propose de retablir l'intercalation Grégorienne, avec une modification trèslegere qui la perfectionnait, sansrendre plus difficile.

Supposons l'année moyenne de $365^{j} 5^{h} 48^{\prime} 48^{\prime \prime}=365 j, 24 \frac{2}{9^{\prime}}$ les $0 j 24 \frac{2}{9}$ en 9 ans feront $2^{j}, 18 ; 10 j, 9$ et 45 ans ; 109 en 450 ans, ou 218 jours en 900 ans, et enfin 872 jours en 3600 ans.

En 3600 ans le calendrier Julien mettait 900 intercalations, c'était 28 de trop. Le calendrier Grégorien ena retranché 27 ; il en reste une à retrancher, ce qui se faitcom modément, en précisant commune l'année 3600 et sesmultiples."

Artinya:

"Saya mengusulkan untuk mengembalikan interkalasi Gregorian, dengan sedikit modifikasi untuk menyempurnakannya, dan tanpa memperumit lagi aturan yang sudah ada.

Misalkan rata-rata tahun 365 hari 5 jam $48^{\prime} 48^{\prime \prime}=365$ hari $24 \frac{2}{9^{\prime}}$ dan 0 hari $24 \stackrel{29}{-}$ dalam 9 tahun akan menjadi 2,18 hari, dalam 45 tahun akan menjadi 10,9 hari, 109 hari dalam 450 tahun, atau 218 hari dalam 900 tahun dan akhirnya 872 hari dalam 3600 tahun.

Selama 3600 tahun kalender Julian memasukkan 900 interkalasisi (28 hari lebih banyak). Kalender Gregorian selama 3600 tahun memasukan 873 interkalasi, juga masih lebih banyak satu hari (1 hari) dari tahun tropis rata-rata. Oleh karena itu, setelah kalender Gregorian melewati masa 3600 tahun beserta kelipatannya, interkalasi harus dikurang satu kali."

Dari kutipan di atas dapat dipahami bahwa Delambre mengajukan perubahan sederhana terhadap aturan kalender Gregorian. Aturan Delambre ini

${ }^{56}$ Delambre, Astronomie Théorique et Pratique Tome Troisiéme, p. 696. 
$176 \mid$ Muhammad Himmatur Riza \& Ahmad Izzuddin

terbilang sederhana karena usulan yang ia ajukan tidak mengubah banyak ketetapan yang ada pada aturan kalender Gregorian. Delambre mengumpamakan panjang satu tahun sipil ${ }^{57}$ rata-rata 365 hari 5 jam 48 menit 48 detik. Nilai tersebut ia peroleh dari hasil perhitungan mencari selisih satu hari antara tiga kalender yang telah digunakan oleh orang-orang masehi Eropa dari masa ke masa. Delambre melakukan penelitian mencari selisih satu hari dengan cara yang cukup sederhana. Ia menjadikan hasil sisa dari nilai tahun tropis yang ia peroleh dari hasil perhitungan bujur ekliptika menjadi pecahan.

Nilai rata-rata tahun tropis versi Delambre apabila dikurangi $365^{\mathrm{h}}\left(365^{\mathrm{h}} 5^{\mathrm{j}}\right.$ $\left.48^{\mathrm{m}} 51.6^{\mathrm{d}}-365^{\mathrm{h}}=5^{\mathrm{j}} 48^{\mathrm{m}} 51.6^{\mathrm{d}}\right)$, kemudian hasilnya dijadikan pecahan berturut-turut dan satu tahun sama dengan 365 hari. Maka pecahan-pecahan tersebut adalah $0.24226=\frac{1}{4}, \frac{7}{29}, \frac{8}{33}, \frac{31}{128}, \frac{39}{161}, \frac{70}{289}$, dan $\frac{109}{450} .{ }^{58}$ Pecahan-pecahan tersebut merupakan refleksi dari aturan penambahan hari interkalasi atau penentuan tahun kabisat dan basitah. Adapun penjelasan dari pecahan-pecahan tersebut sebagai berikut: ${ }^{59}$ a. Pecahan $\frac{1}{4^{\prime}}$ artinya terdapat satu hari interkalasi dalam 4 (empat) tahun. Konsep ini sama dengan konsep kalender Julian. Tetapi nilai tersebut tidak cocok dan terlalu jauh dengan sisa rata-rata tahun tropis.

b. Pecahan $\frac{7}{29^{\prime}}$, artinya satu siklus sama dengan 29 tahun dan tujuh hari interkalasi. Apabila menggunakan konsep ini, akan terjadi kerumitan dalam merealisasikannya. Karena jika diberlakukan, pelaksanaannya terdapat 6 hari interkalasi setiap 24 tahun pertama dan yang ketujuh dilakukan setelah 5 (lima) tahun di tahun ke-29. Selain itu satu tahun rata-rata 365 hari 47 menit 35 detik. Hal ini terlalu cepat dibandingkan dengan tahun tropis Delambre sehingga dikhawatirkan akan muncul persoalan baru.

c. Pecahan $\frac{8}{33^{\prime}}$ artinya terdapat 8 (delapan) hari interkalasi dalam 33 tahun. hari ke-8 akan mengambil bagian setelah 5 (lima) tahun.

d. Pecahan $\frac{31}{128}$, artinya ada 31 hari interkalasi dalam 128 tahun. Apabila pecahan tersebut dipecah kembali akan membuat aturan yang cukup sulit dan rumit, yakni $\frac{31}{128}=\frac{3.8+7}{3.33+29}$. Nilai tersebut merupakan sebuah aturan interkalasi yang rumit dan akan ada 4 (empat) periode, tiga pertama dengan pecahan $\frac{8}{33}$, dan satu yang terakhir dengan pecahan $\frac{7}{29}$.

e. Pecahan $\frac{39}{161^{\prime}}$ artinya $\frac{39}{161}=\frac{31+8}{128+33}=\frac{4.8+7}{4.33+29}$. Pecahan tersebut memiliki arti bahwa terdapat 4 (empat) kali periode $\frac{8}{33}$, dan satu periode $\frac{7}{29}$. Hal ini juga akan memperumit aturan interkalasi.

f. Pecahan $\frac{109}{450}=\frac{872}{3600}$, artinya hanya memberikan 872 hari interkalasi dalam 3600 tahun. Nilai tersebut tentu berbeda dengan aturan interkalasi kalender Julian

57 Tahun sipil adalah tahun yang digunakan suatu negara untuk tujuan sipil, formil atau administrasi. kalender sipil yang paling luas dan standar internasional de facto adalah kalender Gregorian.

58 Jean Baptiste Joseph Delambre, Historie de I'Astronomie Moderne (Paris: Mme Ve COURCIER, LIBRARIE POUR LES SCIENCES, 1821), p. 73.

${ }^{59}$ Ibid., p. 74. 
dan kalender Gregorian. Apabila kalender Julian itu 900 hari dan kalender Gregorian itu 873 hari.

Berdasarkan penjabaran dari pecahan-pecahan tersebut, Delambre menjadikan pecahan $\frac{109}{450}=\frac{872}{3600}$ sebagai pengganti kalender Gregorian. Sedangkan nilai pecahan yang lain bukanlah aturan yang disarankan Delambre karena hanya memperumit penambahan interkalasi.

Penelitian yang dilakukan Delambre di atas dapat dibuktikan bahwa dalam jangka waktu 3600 tahun harus ada 872 tahun kabisat. Berikut ini adalah persamaan yang membuktikan bahwa 365 hari 5 jam 48 menit 48 detik merupakan ekuivalen dengan aturan 872 tahun kabisat dalam 3600 tahun. Nilai tersebut memberikan selisih 1 hari dengan kalender Gregorian dan selisih 28 hari dengan kalender Julian.

$365^{\mathrm{h}} 5^{\mathrm{j}} 48^{\mathrm{m}} 48^{\mathrm{d}}=365^{\mathrm{h}} 5^{\mathrm{j}} 48.8^{\mathrm{m}}=365^{\mathrm{h}} 5.81333^{\mathrm{j}}=365.2422222$ hari $=365.25-$ $0.0077777=365 \frac{1}{4}-\frac{0.007}{9}=365 \frac{1}{4}-\frac{7}{900}=365 \frac{1}{4}-\frac{28}{3600}$.

Berdasarkan persamaan tersebut, dapat diambil simpulan bahwa rata-rata panjang satu tahun sipil yang diusulkan Delambre adalah 365 hari 5 jam 48 menit 48 detik. Kemudian digenapkan dalam satu tahun menjadi 365 hari untuk tahun basit\}ah dan sisanya 5 jam 48 menit 48 detik atau $0.24 \frac{2}{9}$ hari atau 0.2422 hari untuk tahun kabisat. Selanjutnya:

a. Jika sisa tersebut diakumulasikan dalam 9 tahun, maka menjadi 2.18 hari $(9 \times 0.2422=2.18)$.

b. Jika sisa tersebut diakumulasikan dalam 45 tahun menjadi 10.9 hari ( $45 \times 0.2422$ $=10.9$ ).

c. Jika sisa tersebut diakumulasikan dalam 450 tahun menjadi 109 hari $(450 \times 0.2422=109)$.

d. Jika sisa tersebut diakumulasikan dalam 900 tahun menjadi 218 hari $(900 \times 0.2422=218)$. Dan

e. Jika sisa tersebut diakumulasikan dalam 3600 tahun menjadi 872 hari $(3600 \times 0.2422=872)$.

Dengan demikian banyaknya jumlah hari interkalasi (tahun kabisat) gagasan Delambre dengan kalender Gregorian pada tahun 3600 memiliki selisih 1 hari, karena jumlah hari interkalasi dalam 3600 tahun kalender Gregorian adalah 873 hari $(3600 \times 0.2425=873)$.

Delambre membandingkan nilai rata-rata tahun sipil yang digunakan untuk memperbarui kalender dengan nilai rata-rata tahun sipil yang digunakan kalender lain. Berikut adalah tabel yang digunakan Delambre untuk membuktikan bahwa nilai rata-rata satu tahun sipil yang tepat adalah $5^{\mathrm{h}} 48^{\mathrm{m}} 48^{\mathrm{d}}$.

\begin{tabular}{|c|c|c|c|}
\hline Nomor & $\mathbf{5}^{\mathrm{h}} \mathbf{4 8}^{\mathrm{m}} \mathbf{4 2}^{\mathrm{d}}$ & $\mathbf{5}^{\mathrm{h}} \mathbf{4 8}^{\mathrm{m}} \mathbf{4 8}^{\mathrm{d}}$ & $\mathbf{5}^{\mathrm{h}} \mathbf{4 8}^{\mathrm{m}} \mathbf{5 4}^{\mathrm{d}}$ \\
\hline 1 & 4.12967 & 4.12844 & 4.12796 \\
\hline 2 & 8.25934 & 8.25688 & 8.25592 \\
\hline 3 & 12.38901 & 12.38532 & 12.38388 \\
\hline
\end{tabular}


${ }_{178} \mid$ Muhammad Himmatur Riza \& Ahmad Izzuddin

\begin{tabular}{|c|c|c|c|}
\hline 4 & 16.51868 & 16.51376 & 16.51184 \\
\hline 5 & 20.64835 & 20.64220 & 20.63980 \\
\hline 6 & 24.77802 & 24.77064 & 24.76776 \\
\hline 7 & 28.90769 & 28.89908 & 28.89572 \\
\hline 8 & 33.03736 & 33.02752 & 33.02368 \\
\hline 9 & 37.16703 & 37.15596 & 37.15164 \\
\hline 10 & 41.29670 & 41.28440 & 41.27960 \\
\hline 31 & 128.01977 & 127.98164 & 127.96676 \\
\hline 39 & 161.05713 & 161.00916 & 160.99044 \\
\hline 70 & 289.07690 & 288.99084 & 288.95720 \\
\hline 109 & 450.13403 & 450.00000 & 449.94764 \\
\hline
\end{tabular}

Tabel 2 : Perbedaan nilai tahun tropis berdasarkan tahun-tahun tertent $u^{60}$

Berdasarkan tabel di atas dan fokus pada periode $\frac{1}{4}, \frac{7}{29^{\prime}}, \frac{8}{33^{3}}, \frac{31}{128^{\prime}}, \frac{39}{161^{\prime}}, \frac{70}{289^{\prime}}$, dan $\frac{109}{450}$ di tahun pertama, kedua, sampai sepuluh perbedaannya memang tidak terlalu jauh. Akan tetapi mulai pada tahun ke-31 sampai 109 terdapat perbedaan yang cukup signifikan. Oleh karena itu, bilangan desimal pada tabel di atas dapat kita ketahui kesalahan-kesalahan yang ada kecuali menggunakan pecahan $\frac{109}{450}$.Pecahan $\frac{109}{450}$ ini yang dijadikan Delambre sebagai dasar panjang rata-rata tahun sipil. Yang mana tahun sipil menurut Delambre yakni, 365 hari 5 jam 48 menit 48 detik.

Sebenarnya pecahan-pecahan $\frac{8}{33}, \frac{31}{128}, \frac{39}{161}$, dan $\frac{70}{289}$ juga bisa digunakan sebagai aturan tahun kabisat dan akurasinya juga cukup valid untuk kebutuhan teori (pengetahun). Akan tetapi pecahan yang paling mudah dan tidak rumit untuk diberlakukan sebagai aturan pembaru kalender Gregorian adalah pecahan yang terakhir yakni, pecahan $\frac{109}{450}$, yang hanya membutuhkan beberapa modifikasi dari koreksi Gregorian dan memiliki akurasi yang tepat. Adapaun pecahan $\frac{109}{450}$ persamaannya dapat ditulis sebagai berikut: 61

$$
\frac{109}{450}=\frac{8.109}{8.450}=\frac{900-28}{3600}=\frac{900-27-1}{3600}=\frac{1}{4}-\frac{3}{400}-\frac{1}{3600} .
$$

Persamaan di atas menunjukkan bahwa pecahan pertama dan kedua merupakan interkalasi Gregorian. Pecahan ketiga menunjukkan bahwa persamaan di atas cukup membuktikan bahwa konsep 3600 dan kelipatannya adalah nilai yang paling dekat dengan rata-rata tahun tropis yaitu, $5^{\mathrm{j}} 48^{\mathrm{m}} 48^{\mathrm{d}}$. Namun pecahan ini belum pasti dan perlu adanya koreksi lagi dikemudian hari. Oleh karena itu Delambre memberikan alternatif lain untuk sementara waktu dengan menulis $\frac{1}{3600+x}$. Apabila $x=400$, maka rumus interkalasinya menjadi sebagai berikut: 62

\footnotetext{
${ }^{60}$ Ibid., p. 74

${ }^{61}$ Ibid., p. 75.

${ }^{62}$ Ibid., p. 75.
} 


$$
\frac{1}{4}-\frac{3}{400}-\frac{1}{4000}=\frac{1000-30-1}{4000}=\frac{969}{4000}=0.24225=5 j 48^{\mathrm{m}} 50.4^{\mathrm{d}}
$$

Melihat alternatif rumus interkalasi diatas, dapat ditarik kesimpulan bahwa persamaan tersebut memiliki nilai yang sama dengan tahun tropis temuan Delambre.

Kalender Masehi yang mengacu pada kalender Gregorian ini memiliki lama 365,2425 hari. Namun kenyataannya siklus satu tahun tropis Matahari pada tahun 2000 rata-rata adalah 365,242199 hari. ${ }^{63}$ Maka antara kalender Masehi dengan siklus tahun tropis memunculkan selisih sekitar 0.0003 hari atau 12 detik setiap tahunnya. Selisih tersebut akan mengakibatkan fenomena astronomis seperti Vernal Equinox akan selalu terjadi 12 detik lebih awal dari tahun sebelumnya. Jika diakumulasikan 12 detik tersebut maka dalam kurun waktu 3600 tahun akan menjadi 1 hari, dalam kurun waktu 7200 tahun akan menjadi 2 hari, dalam kurun waktu 10.000 tahun akan menjadi 3 hari dan dalam kurun waktu 100.000 tahun selisih antara Vernal Equinox akan menjadi 30 hari atau satu bulan dari tahun sebelumnya.

Gagasan Delambre masih sebatas usulan, yang dikemukakan dalam bukunya berjudul Astronomie Theorie et Pratique Tome Troisieme. Tepatnya pada halaman 696, Bab 38: Du Calendrier (Kalender) di poin 30. Belum ada suatu kelompok tertentu yang tercatat telah atau masih menggunakan konsep kalender Delambre ini. Dalam buku tersebut, Delambre menyatakan hanya sedikit memodifikasi dan tidak menambah kerumitan dari aturan Gregorian yang sudah ada. Satu tahun tetap 12 bulan, satu minggu tetap terdiri dari tujuh hari, penambahan hari interkalasi tetap di bulan Februari. Epoch pun tetap 1 Januari 1 M pukul 00.00. Bulan Januari, Maret, Mei, Juli, Agustus, Oktober, dan Desember tetap berjumlah 31 hari, bulan April, Juni, September, dan November pun tetap berjumlah 30 hari. Modifikasi yang dilakukan Delambre adalah mengurangi jumlah hari interkalasi kalender Gregorian dari 873 hari per 3600 tahun, menjadi 872 hari per 3600 tahun. Adapun aturan penentuan tahun kabisat yang diusulkan Delambre sebagai berikut:

Setiap tahun yang habis dibagi empat adalah tahun kabisat, kecuali untuk tahun-tahun yang habis dibagi 100, hanya bisa menjadi tahun kabisat jika habis dibagi 400, dan tahun yang habis dibagi 3600 adalah tahun kabisat. Jadi penerapan gagasan Delambre akan dilaksanakan pertama kali dimulai dengan dihapusnya tanggal 29 Februari $2800 \mathrm{M}$ hari Selasa kalender Gregorian.

Dalam 3600 tahun ada 872 kali interkalasi. Tahun 2800 dipilih sebagai tahun kabisat yang diubah menjadi tahun basitoh. Karena pada tahun 2800, ekuinoks hampir terjadi di tanggal 19 Maret 2800 M, apabila menunggu sampai tahun 3200 atau bahkan tahun 3600, maka ekuinoks diprediksi sudah benarbenar terjadi di tanggal 19 Maret. oleh karena itu untuk menghindari terulangnya kesalahan di masa lalu, usulan Delambre akan lebih bermanfaat bila diterapkan pada tahun 2800 M. selain itu, jumlah hari rata-rata dalam satu tahun gagasan Delambre menjadi lebih dekat dengan tahun tropis hanya selisih 3 detik per tahun.

${ }^{63}$ Raharto, “Tinjauan Reformasi Kalender Surya”, p. 243. 
$180 \mid$ Muhammad Himmatur Riza \& Ahmad Izzuddin

\begin{tabular}{|c|c|c|c|c|c|c|c|}
\hline Tahun & Delambre & Gregorian & Ket. & Tahun & Delambre & Gregorian & Ket. \\
\hline 2000 & Kabisat & Kabisat & Sama & 6400 & Basitah & Kabisat & Beda \\
\hline 2400 & Kabisat & Kabisat & Sama & 6800 & Kabisat & Kabisat & Sama \\
\hline 2800 & Basitah & Kabisat & Beda & 7200 & Kabisat & Kabisat & Sama \\
\hline 3200 & Kabisat & Kabisat & Sama & 7600 & Kabisat & Kabisat & Sama \\
\hline 3600 & Kabisat & Kabisat & Sama & 8000 & Kabisat & Kabisat & Sama \\
\hline 4000 & Kabisat & Kabisat & Sama & 8400 & Kabisat & Kabisat & Sama \\
\hline 4400 & Kabisat & Kabisat & Sama & 8800 & Kabisat & Kabisat & Sama \\
\hline 4800 & Kabisat & Kabisat & Sama & 9200 & Kabisat & Kabisat & Sama \\
\hline 5200 & Kabisat & Kabisat & Sama & 9600 & Kabisat & Kabisat & Sama \\
\hline 5600 & Kabisat & Kabisat & Sama & 10000 & Basitah & Kabisat & Beda \\
\hline
\end{tabular}

Tabel 3: Perbandingan Kalender Delamre dengan Gregorian

Menurut tabel di atas tampak bahwa dalam kurun waktu 10000 tahun gagasan Delambre akan menghilangkan tiga tahun kabisat, hal ini berarti bahwa gagasan Delambre nantinya akan memperkecil kesalahan Gregorian.

\section{Dampak penerapan gagasan Delambre terhadap jadwal waktu Salat}

Data-data data yang digunakan dalam penentuan waktu salat mengacu pada kalender Gregorian. Misalnya, untuk menentukan waktu salat pada tanggal 23 September datanya berbeda dengan menentukan waktu salat pada 14 Juni. Dengan munculnya gagasan Delambre yang mengubah tatanan kalender Gregorian, penggunaan data-data penentuan waktu salat juga harus mengikuti tatanan gagasan Delambre. Logikanya adalah, Jika menurut gagasan Delambre tanggal 29 Februari 2800 kalender Gregorian harus dihilangkan, maka data-data deklinasi pada tanggal tersebut juga dihilangkan. Namun, permasalahan yang muncul adalah ketika gagasan Delambre tidak diterapkan dan tanggal 29 Februari 2800 masih ada, apakah data deklinasi dan equation of time pada tanggal 29 Februari 2800 tersebut sudah benar dan bisa digunakan sebagai penentu awal waktu salat pada tanggal 29 Februari 2800? Beberapa data yang bergantung pada penanggalan adalah data deklinasi dan equation of time.

1. Deklinasi

Jarak yang dibentuk lintasan Matahari dengan khatulistiwa dinamakan deklinasi. Deklinasi di belahan langit bagian utara adalah positif (+), sedang di bagian selatan adalah negatif (-). Ketika Matahari melintasi khatulistiwa deklinasinya $0^{\circ}$. Hal ini terjadi sekitar tanggal 21 Maret dan tanggal 23 September. ${ }^{64}$

Rumus mencari deklinasi adalah $\delta$ matahari $=\arcsin \left(\sin \left(-23.44^{\circ}\right) . \sin \right.$ (EL)), EL adalah bujur matahari atau posisi bumi pada orbitnya. Bujur matahari pada tanggal 29 Februari 2800 berbeda dengan bujur matahari pada tanggal 1

\footnotetext{
${ }^{64}$ Moelki Fahmi Ardliansyah, “Implementasi Koordinat Tengah Kabupaten Atau Kota Dalam Perhitungan Jadwal Waktu Salat," Al-Ahkam 27 (2017):, p. 235.
} 
Maret 2800. Gagasan Delambre memiliki nilai yang lebih dekat dengan tahun tropis, artinya untuk mendapatkan nilai deklinasi yang lebih tepat (lebih dekat dengan tahun tropis lebih tepat), adalah menggunakan gagasan Delambre. Dengan kata lain, tidak mencari deklinasi pada tanggal 29 Februari 2800 tetapi mencari deklinasi pada tanggal 1 Maret 2800 untuk menentukan waktu salat pada tanggal 29 Februari 2800.

2. Equation of Time

Equation of Time merupakan selisih waktu antara waktu Matahari hakiki dengan waktu Matahari rata-rata (pertengahan). Dalam ilmu Falak biasa dilambangkan dengan huruf e. Sama halnya dengan deklinasi, bergantung pada posisi bumi pada orbitnya nilai equation of time berbeda-beda setiap harinya. Untuk mencari equation of time lebih dekat dengan tahun tropis matahari dan lebih tepat, maka data yang digunakan adalah data equation of time pada tanggal 1 Maret 2800 dalam menentukan waktu salat zuhur pada tanggal 29 Februari 2800.

\section{Implikasi gagasan Delambre tentang pembaruan kalender masehi terhadap jadwal waktu Salat}

Fikih sebagai aturan ibadah amaliah Islam memiliki kaitan yang erat dengan Ilmu Falak, khususnya kalender. Peranan kalender dalam fikih sebagai panduan dalam menentukan waktu, menjadikan kalender unsur penting bagi keberlangsungan fikih yang ideal. Ibadah-ibadah pokok kita, seringkali tidak terlepas kaitannya dengan waktu. Di situ fungsi kalender menjadi penting sebagai alat penentu jadwal ibadah. Dalam Islam ada kalender Hijriah, yang merupakan penemuan fundamental dalam peradaban Islam rahmatan lil alamin. Kalender Hijriah adalah komponen utama dalam ibadah Islam, karena sebagian besar ibadah merujuk pada kalender tersebut. Saat ini kalender ada berbagai macam dan jenis dengan aturan dan ketentuan masing-masing. Di Indonesia, yang mayoritas penduduknya adalah Muslim, malah menggunakan kalender Masehi sebagai kalender resmi negara, dan bukan menggunakan kalender Hijriah. Hai ini disebabkan oleh penjajahan Belanda terhadap Indonesia yang sangat lama, sehingga masyarakat juga mengikuti kalender yang mereka gunakan dan menjadi terbiasa akan hal itu.

Kita telah membahas bagaimana usulan Delambre dalam memperbarui kalender Gregorian dengan cara menghilangkan tanggal 29 Februari 2800 M. Pembahasan di atas menjelaskan pada kita bahwa penghapusan tahun kabisat setiap 3600 tahun sekali dapat mengurangi akumulasi kesalahan kalender Gregorian terhadap tahun tropis. Dengan begitu, segala aspek yang menggantungkan nilai pada kalender Gregorian bisa sesuai dengan realitas alam. Tak terkecuali penentuan waktu salat yang datanya sangat tergantung kepada jadwal pergerakan matahari. Salat adalah ibadah yang pelaksanaannya didasarkan pada waktu-waktu yang telah ditentukan. Dalam menentukan waktuwaktu salat harus merujuk pada dalil-dalil dan syariat. Mengerjakan salat bukan pada waktunya dapat menjadi sebuah pelanggaran terhadap syariat Islam. Salat lima waktu memerlukan pengetahuan posisi matahari dan posisi geografis tempat 
$182 \mid$ Muhammad Himmatur Riza \& Ahmad Izzuddin

di bumi, karena jadwal ibadah salat lima waktu itu merentang dalam satu hari dan menaut dengan fenomena astronomi. Seiring berkembangnya ilmu pengetahuan, penentuan waktu salat juga semakin akurat mendekati sempurna dengan berbagai perhitungan yang cermat. Dalam penentuan awal waktu salat data astronomis terpenting adalah posisi matahari dalam koordinat horizon, terutama ketinggian atau jarak zenith.

Penulis menggunakan dua metode untuk mengetahui implikasi terhadap jadwal waktu salat yang muncul dari gagasan Delambre sebagai usulan pembaruan kalender Gregorian sebagai usulan pembaruan kalender Masehi, yakni menggunakan aplikasi Accurate Times dan program waktu salat Microsoft Excel karya Rinto A Nugraha. Sebagai contoh, penulis menghitung awal waktu salat pada tanggal 29 Februari 2800. Adapun implikasinya sebagai berikut:

1. Awal Waktu Dzuhur

a. Bila menggunakan software Accurate Times keduanya memiliki awal waktu Dzuhur yang sama.

b. Bila menggunakan program waktu salat Microsoft Excel karya Rinto A Nugraha hasilnya untuk waktu salat Dzuhur ada perbedaan. Bila yang dimasukan sebagai data adalah deklinasi Matahari dan equation of time untuk tanggal 29 Februari $2800 \mathrm{M}$, hasilnya 12:09 WIIB. Sedangkan bila yang dimasukan sebagai data adalah deklinasi Matahari dan equation of time untuk tanggal 1 Maret 2800, hasilnya 12:08. Artinya data EoT 29 Februari 2800 lebih lambat dari data 1 Maret 2800.

2. Awal Waktu Asar

a. Menggunakan perangkat lunak Accurate Times hasilnya berbeda satu menit. Hasil awal waktu Asar menggunakan data deklinasi Matahari dan equation of time tanggal 29 Februari 2800 lebih lama 1 menit dari pada data deklinasi Matahari dan equation of time untuk 1 Maret $2800 \mathrm{M}$. atau tepatnya pukul 15:09 WIB banding 15:08 WIB berurutan.

b. Sedangkan menggunakan program Microsoft Excel karya Rinto A Nugraha, hasilnya juga, berbeda satu menit. Hasil awal waktu asar menggunakan data deklinasi Matahari dan equation of time tanggal 29 Februari 2800 lebih lama 1 menit dari pada data deklinasi Matahari dan equation of time untuk 1 Maret $2800 \mathrm{M}$. atau tepatnya pukul 15:11 WIB banding $15: 10$ WIB berurutan.

3. Awal Waktu Maghrib

Awal waktu salat Maghrib menggunakan kedua metode dan kedua data deklinasi Matahari dan equation of time hasilnya sama, yaitu 18:12.

4. Awal Waktu Isya

a. Menggunakan perangkat lunak Accurate Times hasilnya berbeda satu menit. Hasil awal waktu Isya menggunakan data deklinasi Matahari dan equation of time tanggal 29 Februari 2800 lebih lama 1 menit dari pada data deklinasi Matahari dan equation of time untuk 1 Maret $2800 \mathrm{M}$. atau tepatnya pukul 19:21 WIB banding 19:20 WIB berurutan. 
b. Menggunakan program waktu salat Microsoft Excel karya Rinto A Nugraha hasilnya sama menggunakan kedua data deklinasi Matahari dan equation of time.

5. Awal Waktu Subuh

Awal waktu salat Subuh menggunakan kedua metode dan kedua data deklinasi Matahari dan equation of time hasilnya sama, yaitu 04:42 WIB.

\section{Kesimpulan}

Joseph Delambre mengusulkan sebuah gagasan berupa modifikasi penentuan tahun kabisat dalam mereformasi kalender Masehi. Siklus ini terjadi setiap 3600 tahun. Aturannya adalah setiap tahun yang habis dibagi empat adalah tahun kabisat, kecuali untuk tahun-tahun yang habis dibagi 100, hanya bisa menjadi tahun kabisat jika habis dibagi 400, dan tahun yang habis dibagi 3600 adalah tahun kabisat. Penerapan gagasan Delambre akan dilaksanakan pertama kali dimulai dengan dihapusnya tanggal 29 Februari $2800 \mathrm{M}$ hari Selasa kalender Masehi.

Penerapan gagasan Delambre sebagai pembaharu kalender Masehi akan berdampak pada penentuan awal waktu salat. Penentuan awal waktu salat ditahun 2800 lebih, tanpa mempertimbangkan kalender gagasan Delambre dapat menyebabkan kesalahan input data astronomis. Dalam hal penentuan waktu salat, data yang terpengaruh adalah data deklinasi matahari dan equation of time. Hasil perhitungan awal waktu salat menggunakan data-data kalender Masehi dan kalender Gagasan Delambre memiliki perbedaan 1 menit dan perbedaan yang muncul tidak memiliki pola yang signifikan. Penggunaan data yang berasal dari kalender Masehi selalu memiliki hasil yang lebih lambat dibanding dengan hasil yang menggunakan data Delambre. Bagaimanapun, implikasi terhadap jadwal waktu salat pada tahun-tahun di atas tahun 2800 menggunakan data deklinasi dan equation of time yang berasal dari kalender Masehi maupun gagasan Delambre tetap diperbolehkan.

\section{Daftar pustaka}

Ardliansyah, Moelki Fahmi. "Implementasi Koordinat Tengah Kabupaten Atau Kota Dalam Perhitungan Jadwal Waktu Salat." Al-Ahkam 27 (2017).

Azhari, Susiknan. Ensiklopedi Hisab Rukyat. 1st ed. Yogyakarta: Pustaka Pelajar, 2005.

Bashori, Muh. Hadi. Penanggalan Islam. Jakarta: PT Elex Media Computindo, 2013.

Darsono, Ruswa. Penanggalan Islam: Tinjauan Sistem, Fiqih Dan Hisab Penanggalan. Yogyakarta: Labda Press, 2010.

Delambre, Jean Baptiste Joseph. Abrégé d'astronomie, Ou Leçons Élémentaired'astronomie Théorique et Pratique. Paris: Mme Ve COURCIER, Imprimeur-Libraire pour les Mathématiques, 1833.

- - - Astronomie Théorique et Pratique Tome Troisiéme. 3rd ed. Paris: Mme Ve COURCIER, Imprimeur-Libraire pour les Mathématiques, 1814.

- - - Historie de I'Astronomie Moderne. Paris: Mme Ve COURCIER, LIBRARIE POUR LES SCIENCES, 1821. 
$184 \mid$ Muhammad Himmatur Riza \& Ahmad Izzuddin

Geofisika, Badan Meteorologi Klimatologi dan. Almanak 2018. Jakarta: BMKG, 2017.

Ghozali, Ahmad. Irsyād Al-Murīd Ilaā Ma'rifah 'Ilm Al-Falāk 'Alā Rașd Al-Jadìd. Sampang: LAFAL, $1436 \mathrm{H}$.

Hambali, Slamet. Almanak Sepanjang Masa: Sejarah Sistem Penanggalan Masehi, Hijriyah Dan Jawa. Semarang: Program Pascassarjana IAIN Walisongo, 2011.

Izzuddin, Ahmad. CV. Karya Abadi Jaya. Semarang: CV. Karya Abadi Jaya, 2015.

Khazin, Muhyiddin. Ilmu Falak Dalam Teori Dan Praktik. Yogyakarta: Buana Pustaka, 2004.

Muhalling, Rusdin. “Bercermin Pada Penanggalan Masehi." Al-'Adl 1 (2008).

Musonnif, Ahmad. Ilmu Falak. Yogyakarta: Teras, 2011.

Nasir, Abdul Karim and M. Rifa Jamaluddin. Mengenal Ilmu Falak: Teori Dan Implementasi. Yogyakarta: Qudsi Media, 2012.

Office, H. M Nautical Almanac. Explanatory Supplement to The Astronomical Ephemeris and The American Ephemeris and Nautical Almanac. London: Her Majesty's Stationery Office, 1961.

Raharto, Moedji. “Tinjauan Reformasi Kalender Surya." In Prosiding Seminar Sehari Astronomi. Bandung: Jurusan Astronomi ITB-Himpunan Astronomi Indonesia, 1995.

Retnoningsih, Suharso dan Ana. Kamus Besar Bahasa Indonesia. 8th ed. Semarang: CV. Widya Karya, 2009.

Richards, E. G. Mapping Time: The Calendar and Its History. New York: Oxford University Press, 1999.

Rohmah, Elva Imeldatur. "Kalender Cina Dalam Tinjauan Historis Dan Astronomis." Jurnal Al-Marshad: Jurnal Astronomi Islam Dan Ilmu-Ilmu Berkaitan Juni (2018).

Ronan, Nicola Abdo Ziadeh, John D. Schmidt, E.J. Bickerman, Chao Lin, J.A.B. van Buitenen, Colin Alistair. "Calendar Chronology." In Encyclopaedia Britannica, 2019. https://www.britannica.com/science/calendar.

Savoie, Jean Meeus dan Denis. "The History of Tropical Year." Journal of Britannia Astronomic Association 102 (1992).

Sudibyo, Muh. Ma'rufin. Sang Nabi Pun Berputar. Solo: Tinta Medina, 2011.

Syarif, Muh. Rasywan. Perkembangan Perumusan Kalendar Islam Internasional (Studi Atas Pemikiran Mohammad Ilyas). Yogyakarta: Pascasarjana UIN Sunan Kalijaga, 2017.

Ten, Antonio E. “Biography of Jean Baptiste Joseph Delambre.” In Biographical Encyclopedia of Astronomers, edited by Dkk Thomas Hockey, Editor: Virginia Trimble, Thomas William, 54. New York: Springer References, 2014.

Ziggelaar, August. "The Papal Bull of 1582 Promulgating A Reform of the Calendar." In Gregorian Reform of The Calendar. Vatikan: Pontifica Academia Scientarium, 1983.

Zwart, Peter Duffett-Smith and Jonathan Zwart. Practical Astronomy With Your Calculator or Spreadsheet. 4th ed. New York: Cambridge University Press, 2011. 